\title{
Synthesis of multivalent host and guest molecules for the construction of multithreaded diamide pseudorotaxanes
}

\author{
Nora L. Löw ${ }^{\ddagger 1}$, Egor V. Dzyuba ${ }^{\ddagger 1}$, Boris Brusilowskij ${ }^{\ddagger 1}$, Lena Kaufmann ${ }^{1}$, \\ Elisa Franzmann ${ }^{2}$, Wolfgang Maison ${ }^{2}$, Emily Brandt ${ }^{3,4}$, Daniel Aicher ${ }^{3,5}$, \\ Arno Wiehe ${ }^{1,3}$ and Christoph A. Schalley ${ }^{* 1}$
}

\section{Full Research Paper}

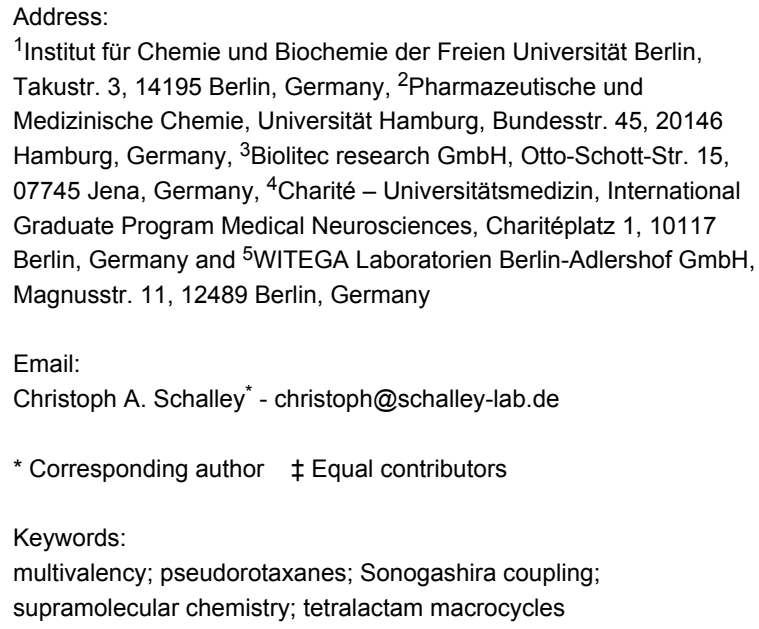

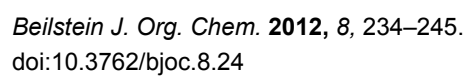

\begin{abstract}
A series of di-, tri- and tetravalent axles and wheels for the synthesis of pseudorotaxanes bearing the tetralactam macrocycle/ diamide axle binding motif was prepared. Starting from iodinated monovalent precursors, Sonogashira cross-coupling reactions were utilized to couple the binding sites to appropriate spacer groups. Through this "Lego" or "toolbox" approach, the convergent synthesis of host and guests with a well-defined number of the binding sites is possible. In addition, the spatial arrangement of the binding sites can be controlled through the quite rigid connections between linker and binding sites. Although a quantitative assessment of binding strengths was not possible by NMR titration experiments, typical and significant shifts of the signals of the diamide moiety indicate qualitatively the formation of pseudorotaxanes from the axle and wheel precursors.
\end{abstract}

\section{Introduction}

Synthetic supramolecular complexes have the great potential to put those concepts to the test that govern much of the noncovalent chemistry in nature. Among these concepts are not only molecular recognition and the noncovalent bonds themselves, but also self-assembly, self-sorting, templation and multivalent binding [1-8]. Consequently, the reductionist investigation of synthetic supramolecules can help us to understand biological systems better. Such a synthetic approach can also help in the 
investigation of multivalent binding [9-12], because the number of binding sites can be altered at will, and studies can be done with a suitable series of host and guest molecules in which the nature and number of binding sites is systematically varied.

Interlocked molecules [13-28] are interesting not only because of their particular topology or the mechanical bond, but also as they have been intensely investigated with respect to the construction of molecular machines [29-32]. The mechanical bond appears particularly suited for this goal, because it connects the axle and wheel strongly, but leaves freedom for the relative movement of the two components. Pseudorotaxanes are the precursors for both rotaxane syntheses by stoppering reactions or catenanes by macrocyclization. The use of weak interactions, e.g., metal complexation [33-47], charge-transfer interactions [48-63], or hydrogen bonding [64-79], between the single building blocks is necessary for efficient templating effects, which aim at assembling higher-order molecular architectures. The synthesis of a multiply threaded architecture $[80,81]$ thus requires multivalent wheel and axle components as precursors, which are also interesting with respect to their binding properties. Among the examples of such multivalent pseudorotaxanes [80-82], the "molecular elevators" reported by Stoddart et al. $[83,84]$ are particularly fascinating, because they combine multivalency with the ability of a molecular device to respond to external stimuli, in this case to acids and bases, which induce motion of the wheel and axle components relative to each other.

Tetralactam macrocycles (TLMs) $[65,66]$ have widely been used in the synthesis of amide catenanes and rotaxanes [85-92] and represent excellent hosts for dicarbonyl compounds [93101]. They bear four converging amide groups, which in each case can form hydrogen bonds to suitable axle molecules in aprotic and not too strongly competitive solvents such as $\mathrm{CH}_{2} \mathrm{Cl}_{2}$ or $\mathrm{CHCl}_{3}$. In this contribution, we report the synthesis and binding behaviour of di-, tri- and tetravalent diamideaxle-TLM complexes. The design is based on the two building blocks $\mathbf{1}$ and $\mathbf{2}$ (Figure 1). Compound $\mathbf{1}$ is the wheel component, and $\mathbf{2}$ is the axle, which comprises a diamide moiety that binds to the wheel as indicated in the center of Figure 1 through the formation of four (wheel) $\mathrm{N}-\mathrm{H} \cdots \mathrm{O}=\mathrm{C}($ axle) hydrogen bonds.

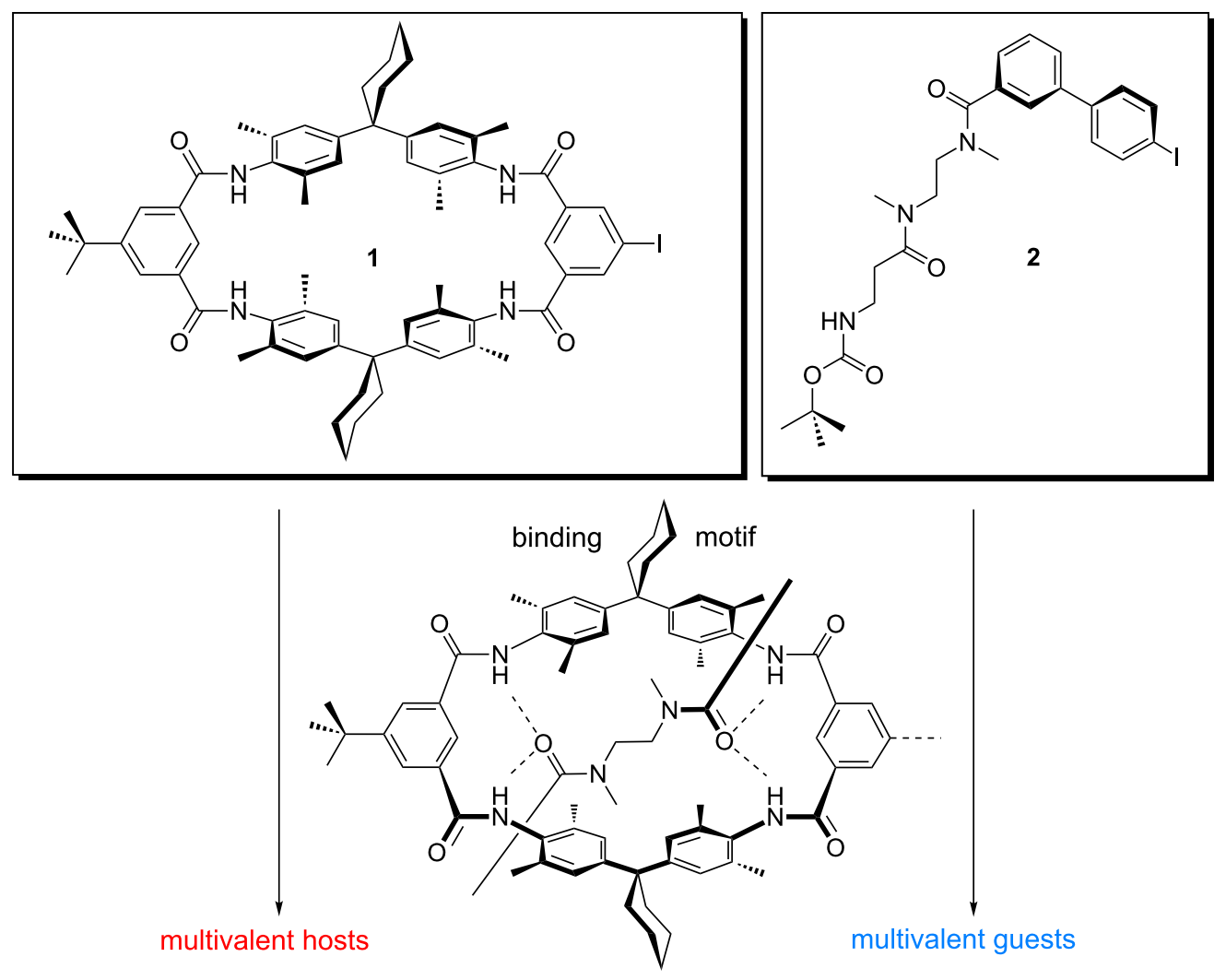

Figure 1: Hunter/Vögtle-type tetralactam macrocycle 1 bearing an iodo substituent at one of the isophthaloyl groups, and the diamide axle piece 2. The iodoaryl groups in both building blocks are suitable for Sonogashira cross-coupling reactions. Therefore, these monovalent precursors can be connected to different suitable spacers so that a "toolbox" of multivalent hosts and guests can be synthesized convergently. The center shows the binding motif, which connects the axle and wheel by four $\mathrm{N}-\mathrm{H} \cdots \mathrm{O}$ hydrogen bonds. 
Through the iodine substituents, both building blocks can be connected to appropriate spacers in Sonogashira cross-coupling reactions [102].

This coupling strategy creates rather rigid connections to the spacers and helps in reducing the entropic penalties that arise from conformational fixing of the spacers upon multivalent binding. The building blocks were chosen based on simple force-field calculations of the resulting pseudorotaxanes and permit us to synthesize a series of different hosts and guests in a convergent way. Thus, a "toolbox" [103,104] of multivalent host and guest molecules becomes available with this synthetic strategy. In the future, the pseudorotaxanes designed here should be easily converted into rotaxanes after cleavage of the Boc protective group at the axle ends and attachment of stopper groups to the terminal amines.

\section{Results and Discussion Synthesis of monovalent precursors}

Although aryl bromides, triflates and sometimes even chlorides react efficiently in Sonogashira cross-coupling reactions, our previous studies $[103,104]$ showed that only the iodinated TLM, and in some rare cases the corresponding triflate-substituted wheel, is reactive enough to provide sufficiently high yields. This is particularly important when the same precursor is to be multiply connected to the same spacer. Low-yielding reaction steps would result in mixtures of the desired compounds with incompletely substituted side products. Therefore, iodo-substi- tuted TLM 1 was prepared according to well-documented literature procedures [64-103] and used for the cross-coupling reactions in this study.

The synthesis of the iodo-substituted monovalent diamide axle centerpiece 2 was realized by the four-step synthesis shown in Scheme 1. The free amino group in mono-Cbz-protected $N, N^{\prime}-$ dimethylethylene diamine 3 [105] was elongated with the commercially available $N$-Boc-protected $\beta$-alanine 4 in the presence of EDC and HOBt as activating coupling reagents. This step provides the basis for future stopper attachment to the axle termini, as mentioned above. Product $\mathbf{5}$ was formed with a yield of $92 \%$ without the need for time-consuming purification steps. This molecule now contains two orthogonal protecting groups, and hydrogenation of $\mathbf{5}$ deprotects the amino group at the $N, N$ '-dimethylethylene diamine site to yield $\mathbf{6}$ in $98 \%$ yield. The iodo-substituted acid $\mathbf{8}$ can easily be prepared under mild conditions from the iodine-free precursor 7 [106] by using $I_{2}$ and phenyliodine diacetate (PIDA) and is then available for amide coupling with 6 yielding binding site 2 in $73 \%$ yield. Since an excess of 7 was used and the 2'/6'-positions are sterically hindered, only monoiodination in the 4'-position was observed. This synthetic pathway thus gives reasonable overall yields.

It should be mentioned that the diamide moiety bears two tertiary amides. All attempts to prepare a similar axle with secondary amide groups failed because of the low solubility of the<smiles>CNCCN(C)C(=O)OCc1ccccc1</smiles>

3

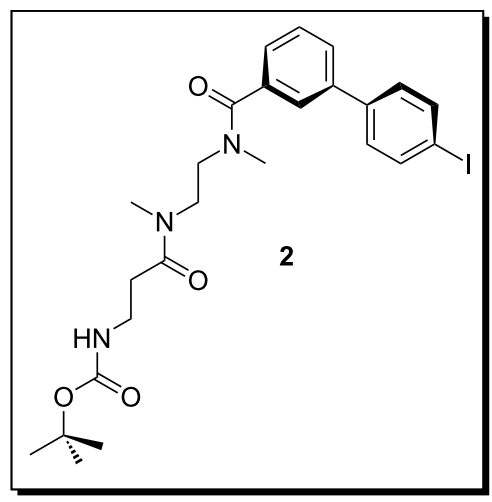<smiles>CC(C)(C)OC(=O)NCCC(=O)O</smiles>

4

(a)<smiles>CN(CCN(C)C(=O)OCc1ccccc1)C(=O)CCNC(=O)OC(C)(C)C</smiles>

5

(b)

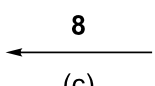<smiles>CNCCN(C)C</smiles>

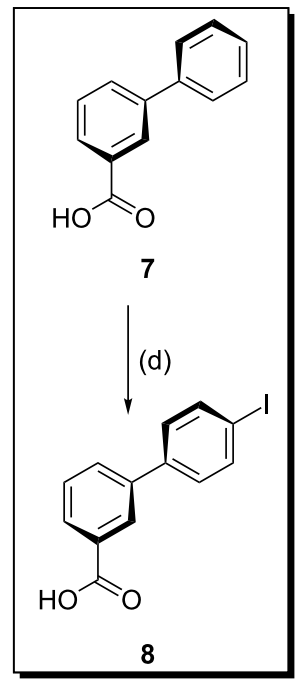

Scheme 1: Synthesis of the monovalent diamide axle 2, which was used for Sonogashira coupling to the appropriate spacers: (a) EDC, HOBt, DMF, 22 h, 92\%; (b) $\mathrm{H}_{2}$, Pd/C, EtOH, 3 d, 98\%; (c) EDC.HCl, HOBt, DMF, 24 h, 73\%; (d) I 2 , PIDA, AcOH/Ac $2 \mathrm{O}, 1$ h, 67\%; (EDC = 1-ethyl-3-(3-dimethylaminopropyl)carbodiimide, $\mathrm{HOBt}=1$-hydroxybenzotriazole, $\mathrm{DMF}=\mathrm{N}, N^{\prime}$-dimethylformamide, $\mathrm{PIDA}=$ phenyliodine diacetate). 
products. This is an important aspect, because the threading of the station into the TLMs requires noncompetitive solvents such as $\mathrm{CH}_{2} \mathrm{Cl}_{2}$ or $\mathrm{CHCl}_{3}$. Consequently, any polar aprotic solvent, such as acetone, acetonitrile, DMF or DMSO, which would solubilize the axles sufficiently well, would interfere strongly with pseudorotaxane formation. The tertiary amides are much more soluble and, therefore, appear to be the more appropriate binding site. However, the better solubility comes at a price. While secondary amides prefer the trans-conformation, in which the carbonyl oxygen and the $\mathrm{NH}$ proton diverge, the tertiary amides do not exhibit a similarly strong preference for one of the conformations. The axle binding sites thus exist in equilibrium between (trans,trans)-, (trans, cis)- and (cis,cis)isomers in solution, which complicates the analysis of the binding properties.

\section{Synthesis of multivalent wheels}

Monovalent axle $\mathbf{2}$ and TLM 1 are designed to give a good complementary fit, when both are connected to the same flat spacer molecules through Sonogashira cross-coupling reactions. Therefore, ethynyl-substituted benzene spacers 9, 11 and 13 were used to synthesize a bent divalent (10), a linear divalent (12), and a trivalent wheel (14) [103] (Scheme 2 and Scheme 3 ). From the enormously broad choice of different

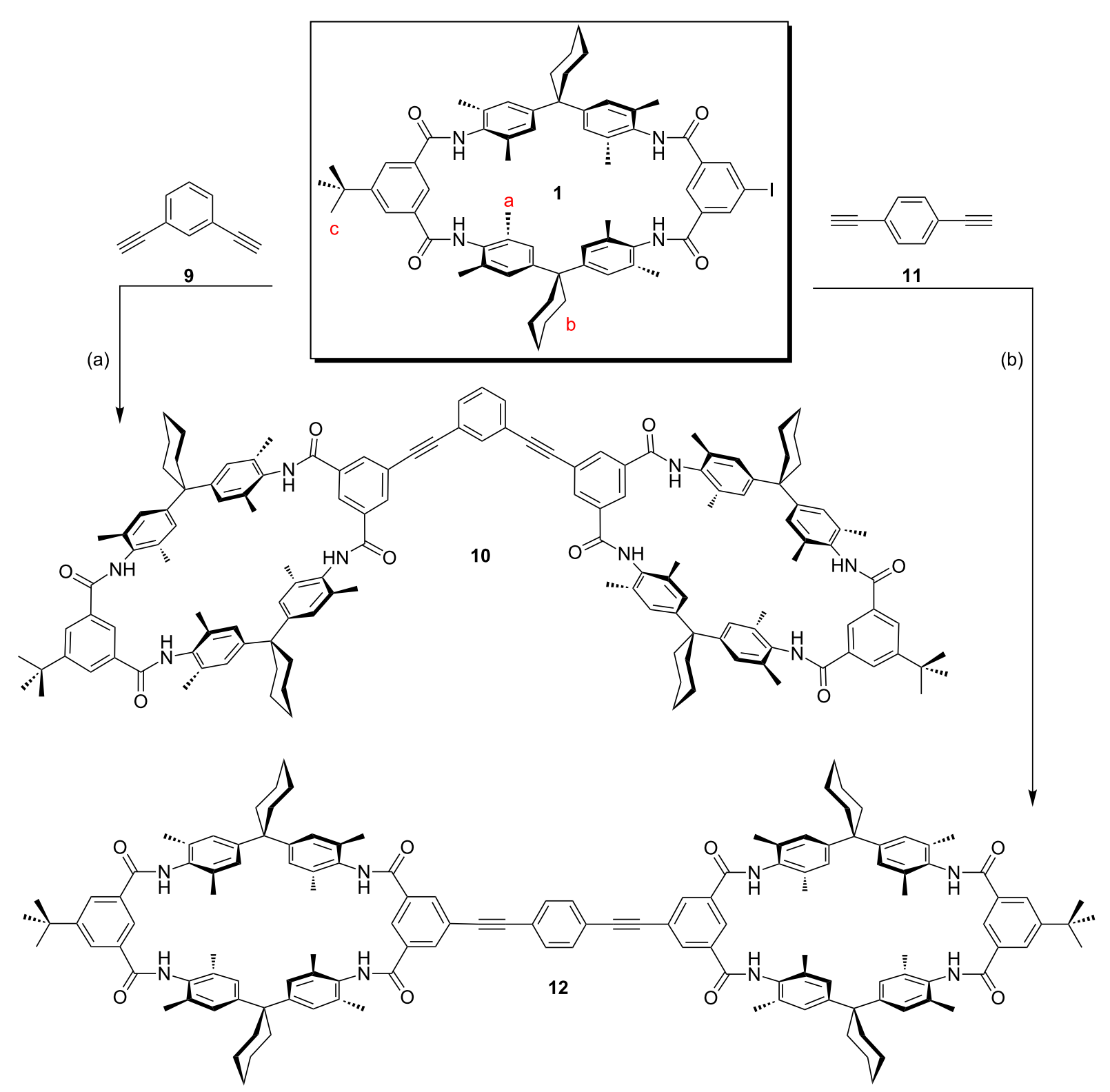

Scheme 2: Synthesis of divalent wheels from TLM 1: (a), (b) $\left(\mathrm{Ph}_{3} \mathrm{P}\right)_{2} \mathrm{PdCl}_{2}, \mathrm{Cul} \mathrm{PPh}_{3}, \mathrm{NEt}_{3}, \mathrm{DMF}, 25^{\circ} \mathrm{C}, 24 \mathrm{~h}, 90 \%(10), 78 \%(12)$. 


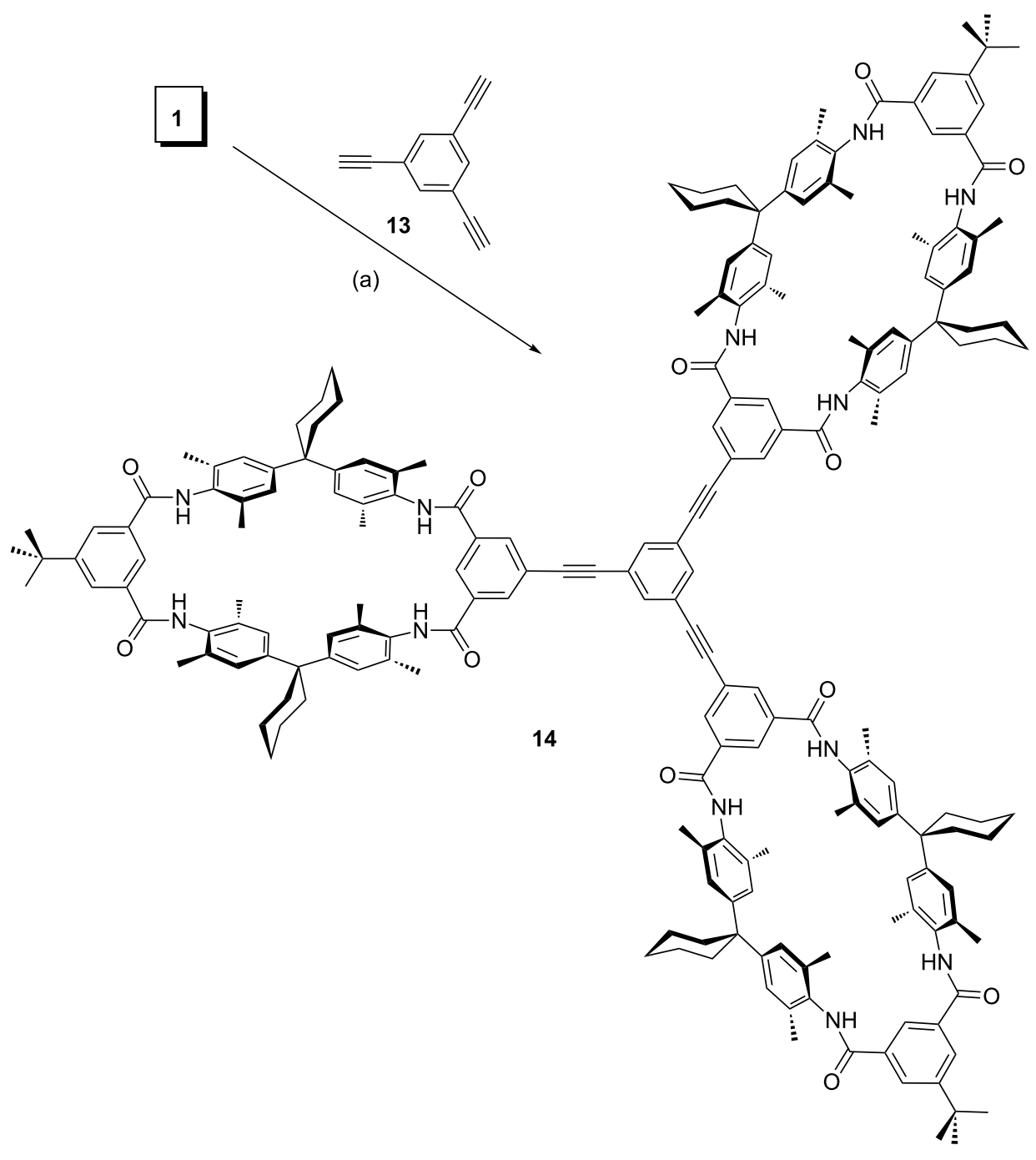

Scheme 3: Synthesis of trivalent wheel 14 from TLM 1: (a) $\left(\mathrm{Ph}_{3} \mathrm{P}\right)_{2} \mathrm{PdCl}_{2}, \mathrm{Cul} \mathrm{PPh}_{3}, \mathrm{NEt}_{3}, \mathrm{DMF}, 2{ }^{\circ} \mathrm{C}, 24 \mathrm{~h}, 40 \%$ (14). Compound 14 was described previously [103] and is included to complete the series.

Pd-catalysts and reaction conditions, we used $\left(\mathrm{Ph}_{3} \mathrm{P}\right)_{2} \mathrm{PdCl}_{2}$ and $\mathrm{CuI}$ in the presence of $\mathrm{PPh}_{3}$ as the coligand, $\mathrm{NEt}_{3}$ as the base, and DMF as the solvent. This protocol was successfully applied previously for the synthesis of $\mathbf{1 4}$ [103]. The yields of $90 \%$ and $78 \%$ obtained for the divalent hosts $\mathbf{1 0}$ and $\mathbf{1 2}$, respectively, were even higher than that for $14(40 \%)$.

All attempts to use the same conditions for the fourfold coupling of 1 to $\mathbf{1 5}$ to synthesize tetravalent wheel $\mathbf{1 6}$ were unsuccessful, and we finally used another procedure for the cross-coupling reaction [107]. Because the $\mathrm{Cu}(\mathrm{I})$ catalyst may interfere with the $\mathrm{Zn}$ core of porphyrin $\mathbf{1 5}$ or lead to Glaser coupled side-reaction products, a copper-free Sonogashira procedure [107,108] employing $\mathrm{Pd}_{2}(\mathrm{dba})_{3}$ as the catalyst and $\mathrm{AsPh}_{3}$ as the coligand in $\mathrm{NEt}_{3} / \mathrm{DMF}$ was applied (Scheme 4). This reaction unfortunately provided only $7 \%$ of the desired tetravalent wheel 16; however, this amount sufficed for characterization by ${ }^{1} \mathrm{H}$ NMR and ESI mass spectrometry. There may be several reasons for this observation. One reason for the low yield may be solubility, which in our experience is always low for tetralactam wheels connected through nicely stacking spacers.

\section{Synthesis of multivalent axles}

In order to prepare the multivalent axles that fit to the wheels described above, the same spacers 9, 11 and $\mathbf{1 3}$ were also used 


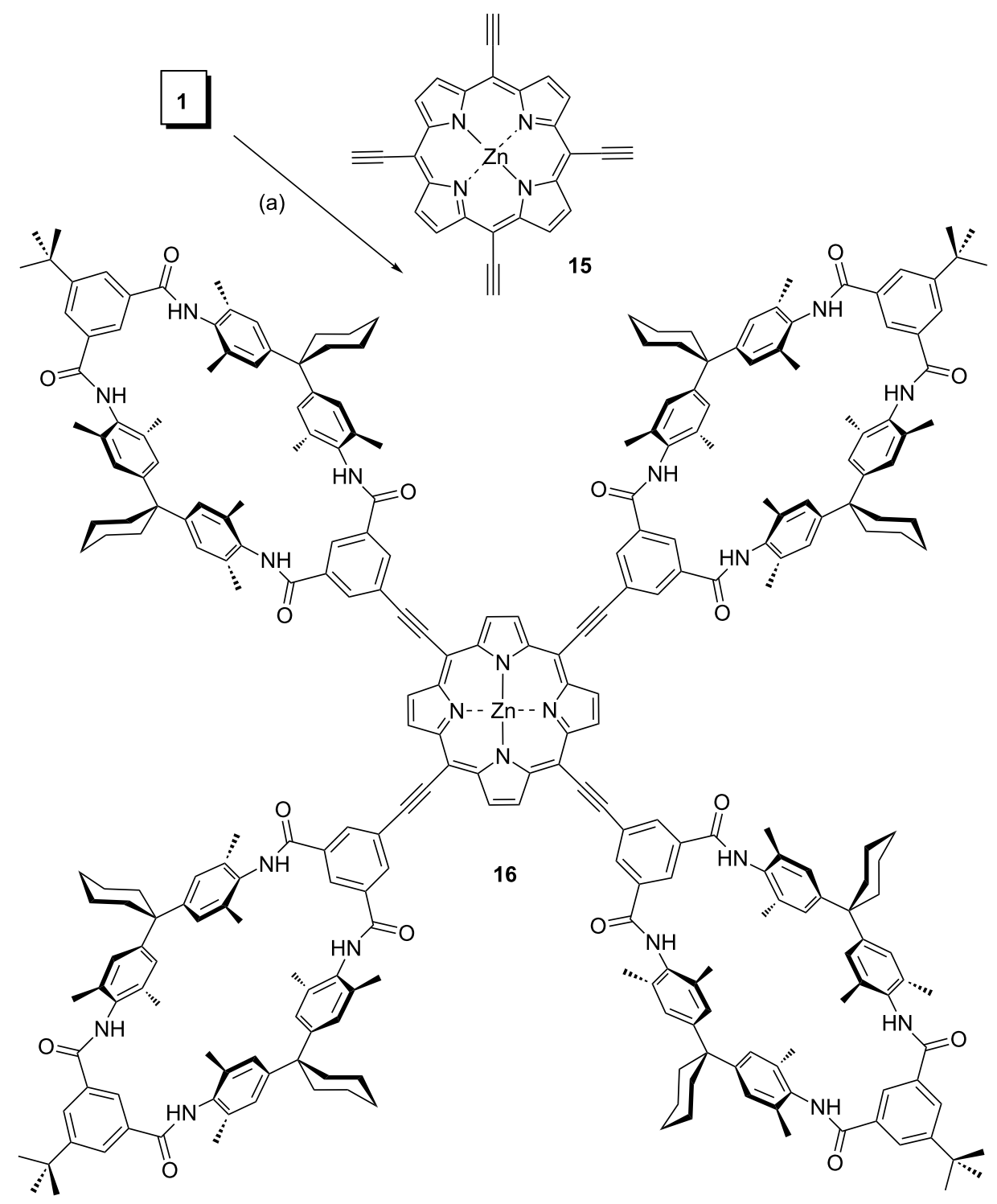

Scheme 4: (a) $\mathrm{Pd}_{2}(\mathrm{dba})_{3}, \mathrm{AsPh}_{3}, \mathrm{NEt}_{3}, \mathrm{DMF}, 120^{\circ} \mathrm{C}, 12 \mathrm{~h}, 7 \%$ (16).

for the synthesis of multivalent guests 17-19, respectively (Scheme 5). In addition, a triethynyl-adamantane derivative $\mathbf{2 0}$ $[109,110]$ was employed in order to prepare an axle component with a slightly different, nonflat spacer geometry.

For the axle preparation, neither the use of $\left(\mathrm{Ph}_{3} \mathrm{P}\right)_{2} \mathrm{PdCl}_{2} / \mathrm{CuI} /$ $\mathrm{PPh}_{3}$ nor that of $\mathrm{Pd}_{2}(\mathrm{dba})_{3} / \mathrm{AsPh}_{3}$ provided the desired products, and therefore the conditions of the Sonogashira crosscoupling reactions had to be optimized again. Finally, the mixture of $\mathrm{Pd}_{2}(\mathrm{dba})_{3} / \mathrm{CuI} / \mathrm{PPh}_{3}$ gave the di- and tritopic axles 17-19 and 21 in DMF/ $/ \mathrm{NEt}_{3}$ with decent yields when the temperature was raised to $70{ }^{\circ} \mathrm{C}$. The copper-free Sonogashira procedure was again applied for the synthesis of tetravalent guest $\mathbf{2 3}$
(Scheme 6) and yielded $17 \%$ of the product. Interestingly, a homocoupling of axle $\mathbf{2}$ gave rise to divalent axle $\mathbf{2 2}$, which was isolated as a side product in $37 \%$ yield. This molecule may be useful for other divalent hosts, such as two macrocycles connected through a butadiyne spacer or a thiophene unit. Such hosts have been reported previously [103] and are not included here.

\section{Formation of pseudorotaxanes}

In order to determine the binding strengths quantitatively, NMR titrations, dilution experiments, and ITC experiments were attempted. The NMR titrations suffer from the fact that different conformations of the tertiary amide groups hamper an in-depth 


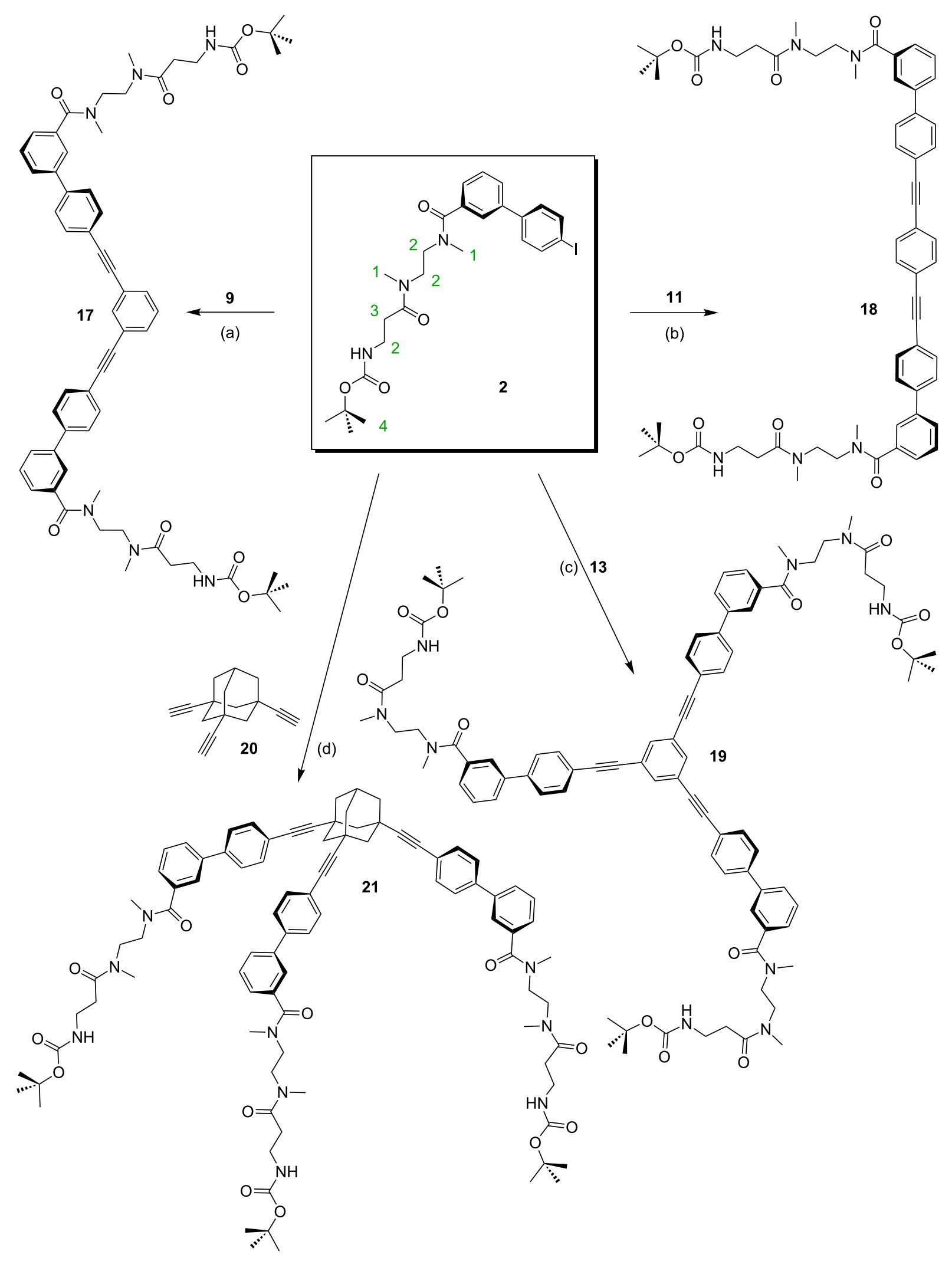

Scheme 5: Synthesis of a series of multivalent guests starting from the axle 2. (a), (b), (c), (d): $\mathrm{Pd}_{2}\left(\mathrm{dba}_{3}, \mathrm{Cul}, \mathrm{PPh}_{3}, \mathrm{NEt} \mathrm{H}_{3}, \mathrm{DMF}, 70{ }^{\circ} \mathrm{C}, 3 \mathrm{~d} ; 32 \%\right.$ (17), 37\% (18), 24\% (19), 64\% (21), respectively. 

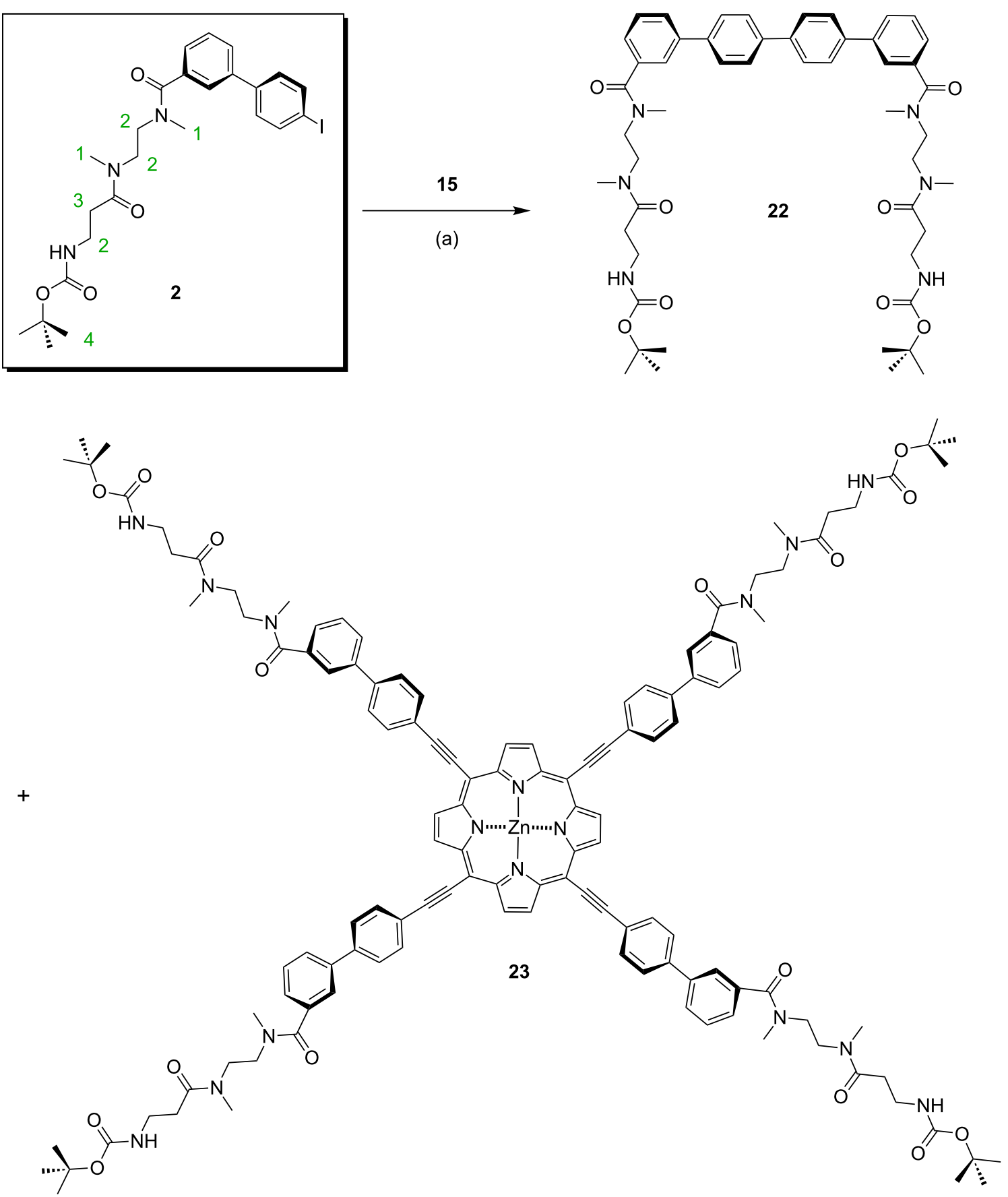

Scheme 6: Synthesis of the tetravalent axle 23 and its divalent side product: (a) $\mathrm{Pd}_{2}(\mathrm{dba})_{3}, \mathrm{AsPh}_{3}, \mathrm{NEt}_{3}, \mathrm{DMF}, 80{ }^{\circ} \mathrm{C}, 2 \mathrm{~d}, 37 \%(\mathbf{2 2}), 17 \%(\mathbf{2 3})$.

evaluation of the titration data. The diamide $\mathrm{N}-\mathrm{CH}_{3}$ and $\mathrm{N}-\mathrm{CH}_{2}$ protons appear with four sets of signals, one for the (trans,trans)-, two for the asymmetric (trans,cis)- and one for the (cis,cis)-isomer. This, and significant signal overlaps, make it impossible to quantify the NMR titration data. For ITC measurements, the concentration range in which one can expect reasonable heats to evolve upon binding could not be reached, due to the low solubility of the wheel components. Furthermore, mass spectrometry was attempted in order to show the formation of $1: 1$ complexes qualitatively, but this was without success. This does not come as a surprise in view of previous theoretical calculations on amide/tetralactam macrocycle complexes [111], which show that simple amide axles dethread in the gas phase because of a favourable entropy term arising from the increase in particle number upon complex dissociation. This entropic contribution overcompensates for the enthalpic 
contribution to the binding. As the calculations were done for monovalent complexes and monoamide, we nevertheless attempted to ionize complexes of our di- and trivalent systems, but unfortunately without success.

However, when ${ }^{1} \mathrm{H}$ NMR spectra of the free axles are compared with the ${ }^{1} \mathrm{H}$ NMR spectra of 1:1 mixtures of axles and wheels, structure-indicative signal shifts are observed that demonstrate the axles to be threaded through the wheels (Figure 2). Consequently, the binding event cannot easily be quantified, but there is qualitative evidence for pseudorotaxane formation. With ${ }^{1} \mathrm{H} /{ }^{1} \mathrm{H}$-COSY NMR experiments, an assignment of, for example, the $\mathrm{N}-\mathrm{CH}_{3}$ groups to two singlets at ca. $3.1 \mathrm{ppm}$ is possible (protons labelled " 1 " in the spectra of $\mathbf{1 7}, \mathbf{1 8}$ and 19 in Figure 2). These signals shift to higher field by ca. $0.9 \mathrm{ppm}$ when 1 equiv of the wheel component is added. These complexation-induced signal shifts are even stronger than similar shifts observed for other rotaxanes with a diamide moiety [101] The fact that proton " 3 " also shifts significantly indicates that binding may also involve the carbonyl group of the Boc protective group. A reversible shuttling between both the diamide station and the outer carbonyl group of that moiety and the Boc group would rationalize this shift easily. Consequently, this preliminary NMR evidence qualitatively provides evidence for binding, while a quantification is not easily possible.

\section{Conclusion}

In conclusion, the synthesis of a "toolbox" of multivalent host and guest molecules has been described, which can be obtained from the two easy-to-prepare building blocks $\mathbf{1}$ and $\mathbf{2}$ by Sonogashira coupling reactions to ethynyl-substituted spacers. This synthetic approach is convergent, and thus the sometimes limited yields do not detract from this approach. With our toolbox, the number and position of binding sites can be varied systematically; hence, the toolbox provides a means to examine multivalency. However, despite the fact that there is qualitative evidence for pseudorotaxane formation, the binding motif is not yet optimal for a quantitative study. Two problems need to be solved: On one hand, the solubility of the hosts needs to be increased such that a concentration range can be reached that enables us to obtain thermochemical data from ITC experiments. On the other hand, a more suitable binding moiety would be advantageous for use in the axles. The tertiary amides obscure a precise analysis of NMR titrations because of the interconverting trans and cis amide conformations. Secondary amides again cause solubility problems. However, as described in a recent article [112], diketopiperazines are quite tightly bound to the TLMs. Equipping our wheels with better solubilizing groups and using diketopiperazine axles should therefore help us to go beyond the limitations encountered in the present study.

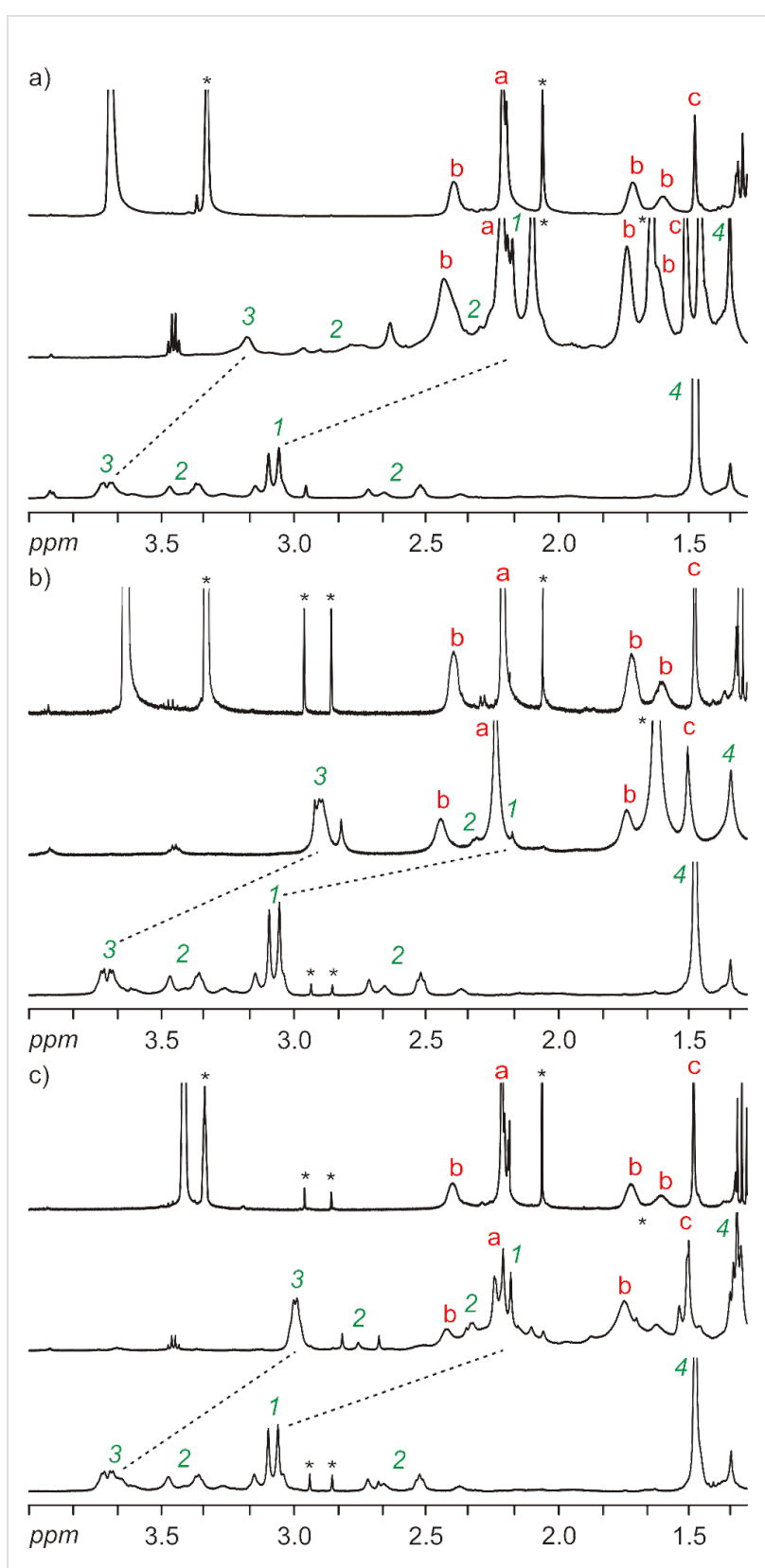

Figure 2: Aliphatic regions of the ${ }^{1} \mathrm{H}$ NMR spectra $\left(\mathrm{CD}_{2} \mathrm{Cl}_{2}, 500 \mathrm{MHz}\right.$, $298 \mathrm{~K}, 2.3 \mathrm{mM}$ ) of (a) 10 (top), $17 @ 10$ (center) and 17 (bottom), (b) 12 (top), 18@12 (center) and 18 (bottom), and (c) 14 (top), 19@14 (center) and 19 (bottom). Because of the low solubility of the wheel components 10,12 and 14, the samples were dissolved in $\mathrm{CD}_{2} \mathrm{Cl}_{2}$ / $\mathrm{CD}_{3} \mathrm{OD}(10: 1)$. Red letters assign signals of the wheels as shown in Scheme 2, green numbers those of the axles as shown in Scheme 5.

\section{Supporting Information}

\section{Supporting Information File 1}

Experimental details and characterization data.

[http://www.beilstein-journals.org/bjoc/content/ supplementary/1860-5397-8-24-S1.pdf] 


\section{Acknowledgements}

This research was funded by the Deutsche Forschungsgemeinschaft (SFB 765 "multivalency") and the Fonds der Chemischen Industrie (FCI). E.V.D. and L. K. thank the Studienstiftung des deutschen Volkes for a PhD scholarship. We thank Gülsah Ayvalik, B.Sc. for her help with the synthesis of starting materials and Dr. Andreas Schäfer for helpful comments on the interpretation of the NMR experiments.

\section{References}

1. Lehn, J.-M. Supramolecular Chemistry - Concepts and Perspectives; Wiley-VCH: Weinheim, Germany, 1995.

2. Sauvage, J.-P.; Dietrich-Buchecker, C. O., Eds. Molecular Catenanes, Rotaxanes, and Knots; Wiley-VCH: Weinheim, Germany, 1999.

3. Gerbeleu, N. V.; Arion, V. B.; Burgess, J. Template Synthesis of Macrocyclic Compounds; Wiley-VCH: Weinheim, Germany, 1999.

4. Diederich, F.; Stang, P. J., Eds. Templated Organic Synthesis; Wiley-VCH: Weinheim, Germany, 2000.

5. Steed, J. W.; Turner, D. R.; Wallace, K. Core Concepts in Supramolecular Chemistry and Nanochemistry; Wiley-VCH: Weinheim, Germany, 2007.

6. Diederich, F.; Stang, P. J.; Tykwinski, R. R., Eds. Modern Supramolecular Chemistry: Strategies for Macrocycle Synthesis; Wiley-VCH: Weinheim, Germany, 2008.

7. Atwood, J. L.; Steed, J. W. Supramolecular Chemistry, 2nd ed.; Wiley: Chichester, U.K., 2009.

8. Ariga, K.; Nalwa, H. S., Eds. Bottom-up Nanofabrication: Supramolecules, Self-Assemblies, and Organized Films; American Scientific Publishers: Valencia, USA, 2009.

9. Mammen, M.; Choi, S.-K.; Whitesides, G. M. Angew. Chem. 1998, 110, 2908-2953. doi:10.1002/(SICI)1521-3757(19981016)110:20<2908::AID-ANGE290 8>3.0.CO;2-2

Angew. Chem., Int. Ed. 1998, 37, 2754-2794. doi:10.1002/(SICI)1521-3773(19981102)37:20<2754::AID-ANIE2754> 3.0.CO;2-3

10. Mulder, A.; Huskens, J.; Reinhoudt, D. N. Org. Biomol. Chem. 2004, 2, 3409-3424. doi:10.1039/b413971b

11. Kiessling, L. L.; Gestwicki, J. E.; Strong, L. E. Angew. Chem. 2006, 118, 2408-2429. doi:10.1002/ange.200502794 Angew. Chem., Int. Ed. 2006, 45, 2348-2368. doi:10.1002/anie.200502794

12. Reczek, J. J.; Kennedy, A. A.; Halbert, B. T.; Urbach, A. R. J. Am. Chem. Soc. 2009, 131, 2408-2415. doi:10.1021/ja808936y

13. Sauvage, J.-P. Acc. Chem. Res. 1998, 31, 611-619. doi:10.1021/ar960263r

14. Blanco, M.-J.; Jiménez, M. C.; Chambron, J.-C.; Heitz, V.; Linke, M.; Sauvage, J.-P. Chem. Soc. Rev. 1999, 28, 293-305. doi:10.1039/a901205b

15. Balzani, V.; Credi, A.; Raymo, F. M.; Stoddart, J. F. Angew. Chem. 2000, 112, 3484-3530. doi:10.1002/1521-3757(20001002)112:19<3484::AID-ANGE3484>3.0. CO;2-O

Angew. Chem., Int. Ed. 2000, 39, 3348-3391. doi:10.1002/1521-3773(20001002)39:19<3348::AID-ANIE3348>3.0.C O;2-X

16. Schalley, C. A.; Beizai, K.; Vögtle, F. Acc. Chem. Res. 2001, 34, 465-476. doi:10.1021/ar000179i
17. Ballardini, R.; Balzani, V.; Credi, A.; Gandolfi, M. T.; Venturi, M. Acc. Chem. Res. 2001, 34, 445-455. doi:10.1021/ar000170g

18. Harada, A. Acc. Chem. Res. 2001, 34, 456-464. doi:10.1021/ar000174l

19. Collin, J.-P.; Dietrich-Buchecker, C.; Gaviña, P.; Jiménez-Molero, M. C.; Sauvage, J.-P. Acc. Chem. Res. 2001, 34, 477-487. doi:10.1021/ar0001766

20. Clemente-León, M.; Credi, A.; Martínez-Díaz, M.-V.; Mingotaud, C.; Stoddart, J. F. Adv. Mater. 2006, 18, 1291-1296. doi:10.1002/adma.200502265

21. Balzani, V.; Credi, A.; Silvi, S.; Venturi, M. Chem. Soc. Rev. 2006, 35, 1135-1149. doi:10.1039/b517102b

22. Credi, A. Angew. Chem. 2007, 119, 5568-5572. doi:10.1002/ange.200700879 Angew. Chem., Int. Ed. 2007, 46, 5472-5475. doi:10.1002/anie.200700879

23. Kay, E. R.; Leigh, D. A.; Zerbetto, F. Angew. Chem. 2006, 119, 72-196. doi:10.1002/ange.200504313 Angew. Chem., Int. Ed. 2007, 46, 72-191. doi:10.1002/anie.200504313

24. Mateo-Alonso, A.; Guldi, D. M.; Paolucci, F.; Prato, M. Angew. Chem. 2007, 119, 8266-8272. doi:10.1002/ange.200702725 Angew. Chem., Int. Ed. 2007, 46, 8120-8126. doi:10.1002/anie.200702725

25. Champin, B.; Mobian, P.; Sauvage, J.-P. Chem. Soc. Rev. 2007, 36, 358-366. doi:10.1039/b604484k

26. Silvi, S.; Venturi, M.; Credi, A. J. Mater. Chem. 2009, 19, 2279-2294. doi:10.1039/b818609j

27. Bodis, P.; Panman, M. R.; Bakker, B. H.; Mateo-Alonso, A.; Prato, M.; Buma, W. J.; Brouwer, A. M.; Kay, E. R.; Leigh, D. A.; Woutersen, S. Acc. Chem. Res. 2009, 42, 1462-1469. doi:10.1021/ar9000845

28. Durot, S.; Reviriego, F.; Sauvage, J.-P. Dalton Trans. 2010, 39 , 10557-10570. doi:10.1039/c0dt00457j

29. Schliwa, M., Ed. Molecular Motors; Wiley-VCH: Weinheim, Germany, 2003.

30. Balzani, V.; Venturi, M.; Credi, A. Molecular Devices and Machines. A Journey into the Nano World; Wiley-VCH: Weinheim, Germany, 2003. doi:10.1002/3527601600

31. Balzani, V.; Credi, A.; Venturi, M. Molecular Devices and Machines: Concepts and Perspectives for the Nanoworld, 2nd ed.; Wiley-VCH: Weinheim, Germany, 2008. doi:10.1002/9783527621682

32. Sauvage, J.-P.; Gaspard, P., Eds. From Non-Covalent Assemblies to Molecular Machines; Wiley-VCH: Weinheim, Germany, 2010. doi:10.1002/9783527632817

33. Dietrich-Buchecker, C. O.; Sauvage, J.-P. Chem. Rev. 1987, 87, 795-810. doi:10.1021/cr00080a007

34. Anderson, S.; Anderson, H. L.; Sanders, J. K. M. Acc. Chem. Res. 1993, 26, 469-475. doi:10.1021/ar00033a003

35. Chambron, J.-C.; Collin, J.-P.; Heitz, V.; Jouvenot, D.; Kern, J.-M.; Mobian, P.; Pomeranc, D.; Sauvage, J.-P. Eur. J. Org. Chem. 2004, 1627-1638. doi:10.1002/ejoc.200300341

36. Amman, M.; Rang, A.; Schalley, C. A.; Bäuerle, P. Eur. J. Org. Chem. 2006, 1940-1948. doi:10.1002/ejoc.200500938

37. Hutin, M.; Schalley, C. A.; Bernardinelli, G.; Nitschke, J. R. Chem.-Eur. J. 2006, 12, 4069-4076. doi:10.1002/chem.200501591

38. Bäuerle, P.; Ammann, M.; Wilde, M.; Götz, G.; Mena-Osteritz, E.; Rang, A.; Schalley, C. A. Angew. Chem. 2007, 119, 367-372. doi:10.1002/ange.200602652 Angew. Chem., Int. Ed. 2007, 46, 363-368. doi:10.1002/anie.200602652 
39. Yamashita, K.-i.; Kawano, M.; Fujita, M. J. Am. Chem. Soc. 2007, 129, 1850-1851. doi:10.1021/ja067132y

40. Meyer, C. D.; Joiner, C. S.; Stoddart, J. F. Chem. Soc. Rev. 2007, 36, 1705-1723. doi:10.1039/b513441m

41. Bonnet, S.; Collin, J.-P. Chem. Soc. Rev. 2008, 37, 1207-1217. doi:10.1039/b713678c

42. Crowley, J. D.; Goldup, S. M.; Lee, A.-L.; Leigh, D. A.; McBurney, R. T. Chem. Soc. Rev. 2009, 38, 1530-1541. doi:10.1039/b804243h

43. Faiz, J. A.; Heitz, V.; Sauvage, J.-P. Chem. Soc. Rev. 2009, 38, 422-442. doi:10.1039/b710908n

44. Collin, J.-P.; Durola, F.; Heitz, V.; Reviriego, F.; Sauvage, J.-P.; Trolez, Y. Angew. Chem. 2010, 122, 10370-10373. doi:10.1002/ange.201004008

45. Clever, G. H.; Shionoya, M. Chem.-Eur. J. 2010, 16, 11792-11796. doi:10.1002/chem.201002013

46. Megiatto, J. D., Jr.; Schuster, D. I.; Abwandner, S.; de Miguel, G.; Guldi, D. M. J. Am. Chem. Soc. 2010, 132, 3847-3861. doi:10.1021/ja910149f

47. Hänni, K. D.; Leigh, D. A. Chem. Soc. Rev. 2010, 39, 1240-1251. doi:10.1039/b901974j

48. Amabilino, D. B.; Stoddart, J. F.; Williams, D. J. Chem. Mater. 1994, 6 , 1159-1167. doi:10.1021/cm00044a014

49. Amabilino, D. B.; Stoddart, J. F. Chem. Rev. 1995, 95, 2725-2828. doi:10.1021/cr00040a005

50. Glink, P. T.; Stoddart, J. F. Pure Appl. Chem. 1998, 70, 419-424. doi:10.1351/pac199870020419

51. Nepogodiev, S. A.; Stoddart, J. F. Chem. Rev. 1998, 98, 1959-1976. doi:10.1021/cr970049w

52. Lee, J. W.; Samal, S.; Selvapalam, N.; Kim, H.-J.; Kim, K. Acc. Chem. Res. 2003, 36, 621-630. doi:10.1021/ar020254k

53. Kim, K.; Selvapalam, N.; Ko, Y. H.; Park, K. M.; Kim, D.; Kim, J. Chem. Soc. Rev. 2007, 36, 267-279. doi:10.1039/b603088m

54. Dichtel, W. R.; Miljanić, O. Š.; Zhang, W.; Spruell, J. M.; Patel, K.; Aprahamian, I.; Heath, J. R.; Stoddart, J. F. Acc. Chem. Res. 2008, 41, 1750-1761. doi:10.1021/ar800067h

55. Griffiths, K. E.; Stoddart, J. F. Pure Appl. Chem. 2008, 80, 485-506. doi:10.1351/pac200880030485

56. Isaacs, L. Chem. Commun. 2009, 619-629. doi:10.1039/b814897j

57. Appel, E. A.; Biedermann, F.; Rauwald, U.; Jones, S. T.; Zayed, J. M.; Scherman, O. A. J. Am. Chem. Soc. 2010, 132, 14251-14260. doi:10.1021/ja106362w

58. Zhang, M.; Zhu, K.; Huang, F. Chem. Commun. 2010, 46, 8131-8141. doi:10.1039/c0cc02717k

59. Au-Yeung, H. Y.; Pantoş, G. D.; Sanders, J. K. M. Angew. Chem. 2010, 122, 5459-5462. doi:10.1002/ange.201000807 Angew. Chem., Int. Ed. 2010, 49, 5331-5334. doi:10.1002/anie.201000807

60. Cougnon, F. B. L.; Au-Yeung, H. Y.; Pantoş, G. D.; Sanders, J. K. M. J. Am. Chem. Soc. 2011, 133, 3198-3207. doi:10.1021/ja111407m

61. Fang, L.; Basu, S.; Sue, C.-H.; Fahrenbach, A. C.; Stoddart, J. F. J. Am. Chem. Soc. 2011, 133, 396-399. doi:10.1021/ja1087562

62. Biedermann, F.; Rauwald, U.; Zayed, J. M.; Scherman, O. A. Chem. Sci. 2011, 2, 279-286. doi:10.1039/c0sc00435a

63. Niu, Z.; Huang, F.; Gibson, H. W. J. Am. Chem. Soc. 2011, 133, 2836-2839. doi:10.1021/ja110384v

64. Hunter, C. A. J. Chem. Soc., Chem. Commun. 1991, 749-751. doi:10.1039/C39910000749

65. Hunter, C. A. J. Am. Chem. Soc. 1992, 114, 5305-5311. doi:10.1021/ja00039a047
66. Vögtle, F.; Meier, S.; Hoss, R. Angew. Chem. 1992, 104, 1628-1631. doi:10.1002/ange.19921041212

Angew. Chem., Int. Ed. 1992, 31, 1619-1622.

doi:10.1002/anie.199216191

67. Ottens-Hildebrandt, S.; Meier, S.; Schmidt, W.; Vögtle, F. Angew. Chem. 1994, 106, 1818-1821.

doi:10.1002/ange.19941061712

Angew. Chem., Int. Ed. 1994, 33, 1767-1770.

doi:10.1002/anie.199417671

68. Vögtle, F.; Dünnwald, T.; Schmidt, T. Acc. Chem. Res. 1996, 29, 451-460. doi:10.1021/ar950200t

69. Kim, K. Chem. Soc. Rev. 2002, 31, 96-107. doi:10.1039/a900939f

70. Schalley, C. A.; Weilandt, T.; Brüggemann, J.; Vögtle, F. Top. Curr. Chem. 2004, 248, 141-200.

71. Kay, E. R.; Leigh, D. A. Top. Curr. Chem. 2005, 262, 133-177. doi:10.1007/128_011

72. Jiang, W.; Winkler, H. D. F.; Schalley, C. A. J. Am. Chem. Soc. 2008, 130, 13852-13853. doi:10.1021/ja806009d

73. Jiang, W.; Schalley, C. A. Proc. Natl. Acad. Sci. U. S. A. 2009, 106, 10425-10429. doi:10.1073/pnas.0809512106

74. Stoddart, J. F. Chem. Soc. Rev. 2009, 38, 1802-1820. doi:10.1039/b819333a

75. Lee, C.-F.; Leigh, D. A.; Pritchard, R. G.; Schultz, D.; Teat, S. J.; Timco, G. A.; Winpenny, R. E. P. Nature 2009, 458, 314-318. doi:10.1038/nature07847

76. Jiang, W.; Mohr, P. C.; Schäfer, A.; Schalley, C. A. J. Am. Chem. Soc. 2010, 132, 2309-2320. doi:10.1021/ja9101369

77. Jiang, W.; Schalley, C. A. Beilstein J. Org. Chem. 2010, 6, No. 14 doi:10.3762/bjoc. 6.14

78. Fang, L.; Olson, M. A.; Benítez, D.; Tkatchouk, E.; Goddard, W. A., III; Stoddart, J. F. Chem. Soc. Rev. 2010, 39, 17-29. doi:10.1039/b917901a

79. Ma, X.; Tian, H. Chem. Soc. Rev. 2010, 39, 70-80. doi:10.1039/b901710k

80. Jiang, W.; Han, M.; Zhang, H.-Y.; Zhang, Z.-J.; Liu, Y. Chem.-Eur. J. 2009, 15, 9938-9945. doi:10.1002/chem.200901206

81. Chen, C.-F. Chem. Commun. 2011, 47, 1674-1688. doi:10.1039/c0cc04852f

82. Badjić, J. D.; Nelson, A.; Cantrill, S. J.; Turnbull, W. B.; Stoddart, J. F. Acc. Chem. Res. 2005, 38, 723-732. doi:10.1021/ar040223k

83. Badjić, J. D.; Balzani, V.; Credi, A.; Silvi, S.; Stoddart, J. F. Science 2004, 303, 1845-1849. doi:10.1126/science.1094791

84. Badjić, J. D.; Ronconi, C. M.; Stoddart, J. F.; Balzani, V.; Silvi, S.; Credi, A. J. Am. Chem. Soc. 2006, 128, 1489-1499. doi:10.1021/ja0543954

85. Reuter, C.; Vögtle, F. Org. Lett. 2000, 2, 593-595. doi:10.1021/ol990350u

86. Affeld, A.; Hübner, G. M.; Seel, C.; Schalley, C. A. Eur. J. Org. Chem. 2001, 2877-2890. doi:10.1002/1099-0690(200108)2001:15<2877::AID-EJOC2877>3.0.C O;2-R

87. Schalley, C. A.; Silva, G.; Nising, C.-F.; Linnartz, P. Helv. Chim. Acta 2002, 85, 1578-1596. doi:10.1002/1522-2675(200206)85:6<1578::AID-HLCA1578>3.0.CO;2 $-\mathrm{L}$

88. Li, X.-y.; Illigen, J.; Nieger, M.; Michel, S.; Schalley, C. A. Chem.-Eur. J. 2003, 9, 1332-1347. doi:10.1002/chem.200390153

89. Linnartz, P.; Bitter, S.; Schalley, C. A. Eur. J. Org. Chem. 2003, 4819-4829. doi:10.1002/ejoc.200300466 
90. Felder, T.; Schalley, C. A. Angew. Chem. 2003, 115, 2360-2363. doi:10.1002/ange.200350903

Angew. Chem., Int. Ed. 2003, 42, 2258-2260. doi:10.1002/anie.200350903

91. Linnartz, P.; Schalley, C. A. Supramol. Chem. 2004, 16, 263-267. doi:10.1080/1061027042000204010

92. Ghosh, P.; Federwisch, G.; Kogej, M.; Schalley, C. A.; Haase, D.; Saak, W.; Lützen, A.; Gschwind, R. M. Org. Biomol. Chem. 2005, 3, 2691-2700. doi:10.1039/b506756a

93. Seel, C.; Parham, A. H.; Safarowsky, O.; Hübner, G. M.; Vögtle, F. J. Org. Chem. 1999, 64, 7236-7242. doi:10.1021/jo990042+

94. Chang, S.-Y.; Kim, H. S.; Chang, K.-J.; Jeong, K.-S. Org. Lett. 2004, 6, 181-184. doi:10.1021/ol035954j

95. Herrmann, U.; Jonischkeit, T.; Bargon, J.; Hahn, U.; Li, Q.-Y.; Schalley, C. A.; Vogel, E.; Vögtle, F. Anal. Bioanal. Chem. 2002, 372, 611-614. doi:10.1007/s00216-001-1230-6

96. Bargon, J.; Braschoß, S.; Flörke, J.; Herrmann, U.; Klein, L.; Lörgen, J. W.; Lopez, M.; Maric, S.; Parham, A. H.; Piacenza, P.; Schäfgen, H.; Schalley, C. A.; Silva, G.; Schlupp, M.; Schwierz, H.; Vögtle, F.; Windscheif, G. Sens. Act. B 2003, 95, 6-19. doi:10.1016/S0925-4005(03)00395-2

97. Kleefisch, G.; Kreutz, C.; Bargon, J.; Silva, G.; Schalley, C. A. Sensors 2004, 4, 136-146. doi:10.3390/s40900136

98. Kossev, I.; Reckien, W.; Felder, T.; Kishan, M. R.; Schalley, C. A.; Sokolowski, M. J. Phys. Chem. C 2009, 113, 12870-12877. doi:10.1021/jp903668x

99. Kossev, I.; Reckien, W.; Kirchner, B.; Felder, T.; Nieger, M.; Schalley, C. A.; Vögtle, F.; Sokolowski, M. Adv. Funct. Mater. 2007, 17, 513-519. doi:10.1002/adfm.200600540

100.Kossev, I.; Felder, T.; Schalley, C. A.; Vögtle, F.; Sokolowski, M. Springer Proc. Phys. 2009, 127, 235-245. doi:10.1007/978-3-540-88201-5_27

101. Hunter, C. A.; Packer, M. J. Chem.-Eur. J. 1999, 5, 1891-1897. doi:10.1002/(SICI)1521-3765(19990604)5:6<1891::AID-CHEM1891>3 .0.CO;2-G

102.Chinchilla, R.; Nájera, C. Chem. Rev. 2007, 107, 874-922. doi:10.1021/cr050992x

103. Baytekin, B.; Zhu, S. S.; Brusilowskij, B.; Illigen, J.; Ranta, J.; Huuskonen, J.; Russo, L.; Rissanen, K.; Kaufmann, L.; Schalley, C. A. Chem.-Eur. J. 2008, 14, 10012-10028. doi:10.1002/chem.200801289

104.Dzyuba, E. V.; Baytekin, B.; Sattler, D.; Schalley, C. A. Eur. J. Org. Chem., in press.

105.Liu, H.-X.; Shao, F.; Li, G.-Q.; Xun, G.-L.; Yao, Z.-J. Chem.-Eur. J. 2008, 14, 8632-8639. doi:10.1002/chem.200801298

106.Kabalka, G. W.; Wang, L. Tetrahedron Lett. 2002, 43, 3067-3068. doi:10.1016/S0040-4039(02)00437-9

107.Kuo, M.-C.; Li, L.-A.; Yen, W.-N.; Lo, S.-S.; Lee, C.-W.; Yeh, C.-Y. Dalton Trans. 2007, 1433-1439. doi:10.1039/b617170b

108.Ljungdahl, T.; Bennur, T.; Dallas, A.; Emtenäs, H.; Mårtensson, J. Organometallics 2008, 27, 2490-2498. doi:10.1021/om800251s

109. Maison, W.; Frangioni, J. V.; Pannier, N. Org. Lett. 2004, 6, 4567-4569. doi:10.1021/ol048055j

110.Pannier, N.; Maison, W. Eur. J. Org. Chem. 2008, 1278-1284. doi:10.1002/ejoc.200701003

111.Spickermann, C.; Felder, T.; Schalley, C. A.; Kirchner, B. Chem.-Eur. J. 2008, 14, 1216-1227. doi:10.1002/chem.200700479

112.Dzyuba, E. V.; Kaufmann, L.; Löw, N. L.; Meyer, A. K.; Winkler, H. D. F.; Rissanen, K.; Schalley, C. A. Org. Lett. 2011, 13, 4838-4841. doi:10.1021/ol201915j

\section{License and Terms}

This is an Open Access article under the terms of the Creative Commons Attribution License

(http://creativecommons.org/licenses/by/2.0), which permits unrestricted use, distribution, and reproduction in any medium, provided the original work is properly cited.

The license is subject to the Beilstein Journal of Organic Chemistry terms and conditions:

(http://www.beilstein-journals.org/bjoc)

The definitive version of this article is the electronic one which can be found at:

doi:10.3762/bjoc. 8.24 